\title{
ASPECTS OF SUSTAINABLE MANAGEMENT CONTROL FOR COMPANY EFFICIENCY
}

\author{
Ionel Bostan ${ }^{1 *}$, Aliona Bîrcă², Neculai Tabără $\breve{3}^{3}$, Ligia Muntean Jemna ${ }^{4}$ \\ 1. Faculty of Law and Administrative Sciences, Stefan cel Mare University of Suceava, 13 Universităţii, \\ 720229 Suceava, Romania; ionel_bostan@yahoo.com \\ 2. Academy of Economic Studies of Moldova, 61 Mitropolit Gavriil Banulescu-Bodoni, Chișinău 2005, \\ Moldova, birca.aliona1@gmail.com \\ 3. Faculty of Economics and Business Administration, Alexandru Ioan Cuza University of Iasi, 11 Carol I, \\ 700506 Iaşi, Romania, neculaitabara@yahoo.com \\ 4. Faculty of Economics and Business Administration, Alexandru Ioan Cuza University of Iasi, 11 Carol I, \\ 700506 Iaşi, Romania, lidgia@gmail.com \\ *Correspondence: $\underline{\text { ionel bostan@yahoo.com or ibostan@fdsa.usv.ro }}$
}

\begin{abstract}
In this article, management control has been studied from the perspective of intention towards sustainable development of companies. The main idea focuses on the analysis of relations between sustainable management control and the system of performance appraisal using as a reference the resource-based theory. These relations have been assessed both theoretically by reviewing literature in the field, and empirically based on data collected in a questionnaire from top management, as well as data from Annual Reports from the main segment of Bucharest Stock Exchange. The authors have shown that financial performance has a significant influence on management control, and the return on capital employed is one of the most recommended indicators. The sustainable nature attributed to management control is the result of institutional theory evolution, provisions of Directive 2014/95/EU and Guide of Global Management Accounting Principles (2015) using stewardship. Consequently, profits are not the main element any more in the assessment of financial ,health" of a company. To ensure the sustainable success, sustainable balanced scorecard is one of real measures for managing financial and non-financial performance.
\end{abstract}

Key-words: sustainable management control; performance evaluation system; resourcebased theory; sustainable balanced scorecard.

\section{Introduction}

Being a guide for executive management, management control aims to optimize performance in order to achieve the strategic business objectives. Many researchers in the field view performance as a control measure specific to decentralised decision making system. Others argue that performance varies depending on the attitude of people in charge of governance regarding the events occurring both inside and outside the company. From this perspective, the 
position of top management is a key factor in ensuring a positive control environment contributing to the implementation of a control system based on performance evaluation.

In discussing performance, we concentrated on special achievements of a company. So, the study aims to answer the following question: What theoretical background may be used for studying the relations between sustainable management control and performance and what is the actual status of companies in Romania? The theoretical research of these relations was carried out in several stages. First, we studied various concepts specific related to performance and its appraisal. The resource-based theory was used as a fundamental background in researching these relations. While financial and non-financial performance supplemented by the sustainable balanced scorecard describe the main features of performance evaluation system.

Three hypotheses were used to test and validate the theoretical approaches. The first hypothesis concerns the relations between management control and company performance. As the study belongs to a broader one, only the elements related to performance relations were selected during each stage of management control. The second hypothesis derives from the first one, and plays the role of showing, which is the most important indicator for assessing financial performance within sustainable management control. The third hypothesis was used to analyse the links between the institutional theory and accounting through stewardship.

\section{Literature review}

Performance has been recently one of the most discussed concepts but it often refers to individual performance, and job appraisal, respectively. In his research, Campbell [1] views it as a "virtual desert ". Other researchers have also underlined that in theoretical approach a distinction should be made between an action behavioural aspect and an outcome aspect of performance. Defining performance, Campbell and other researchers state that any behaviour may be attributed to this concept but only the behaviour relevant for the organizational objectives: „Performance is what a company is committed to deliver and it is good". In the interpretation of the definition presented above, other researchers contend that performance is not action as such but evaluation processes and decisions [1]. Moreover, Campbell says that only operations that could be scaled and measured may be viewed as performance.

Literature in the field developed two types of performance measurement: formal and informal. The formal dimension involves a multitude of instruments. Managerial accounting plays an important role in assessing the cost of goods and services, developing the system of budgets and assessing commercial performance using a set of indicators. The informal dimension refers to indicators and information that are less verified by the formal system and addresses intangible phenomena [2].

Le Maitre [3] believes that the validation of performance appraisal results depends on the quality of records and observations of the assessor. Also, it depends on the process of appraisal between superiors and subordinates. T.R. Lowe [3] identified eight potential problems or errors that may appear in this process:

- the assessor overvaluated performance, the assessed persons obtained good results in an area viewed by the assessor as being essential - the ,halo effect”; 
- the assessor undervalued the performance as the assessed persons obtained expected events in a specific area - contrary to the ,halo effect”;

- the assessor did not use all grades in appraisal - „effect of central tendency". The assessed individuals were assessed at the same level and it does not allow their differentiation;

- in the process of appraisal of performance, the assessor uses mostly recent results without considering the entire period that is being appraised - the „effect of neglecting the past";

- the assessor does not see as appropriate the consideration of past performance of an appraised individual. He believes that an employee should meet the current and future requirements;

- to avoid conflicts, the superior as appraiser does not divulge the weaknesses of a subordinate;

- the superiors expect from subordinates exceptional results, that is why none of them was given the proper grades;

- the level of performance of the superior depends on the levels of subordinates. Therefore, no subordinate obtained a higher grade from a subordinate.

According to ideas of A. Braganza, H. Stebbings and Th. Ngosi [4], the resource-based theory approaches management control in terms of performance. Other researchers believe that this theory focuses on the selection and management of heterogeneous resources by companies in order to obtain advantages under sustainable development. According to Peteraf (1993), assets and internal and external capacities of companies are viewed as resources, Sveiby (1997) views assets as emerging and divides them into two categories: tangible (financial and technological) and intangible (competencies of employees and organisational processes) assets. In this sense, the roles of management control multiply due to the fact that they should appraise the way in which a company manages resources by maintaining the VRIN (Valuable, Rare, Inimitable, Nonsubstitutable) elements of Penrose (1959) and Barney (1991), succeeding to be competitive on the market [4].

In his paper, Y. Liu [5] linked the budgets to management control identifying four stages in the development of the budgetary system: executive budget period (1910-1935), period of performance based on budgets (1940-1960), system of programming period, planning and budgeting (1965 - mid 90s), budget reform period (from the mid-90s). The last stage is characterised by a global approach oriented towards control, planning and integration of budgets into strategic planning.

Proponent of the view of professional institutions in the field regarding the relations between management control and business performance, ACCA [6] starts from the idea that companies have both financial and non-financial objectives, such as: provision of efficient services, growth of market share or reduction of environmental impact. There are several very important areas that ensure the success of a business, and the use of non-financial indicators plays a key role. In this context, we may mention that non-financial performance indicators are used for assessing information delivered by human resources, marketing and production departments playing the role of supervising and controlling business operations without using accounting principles. The quality of services is one of the main indicators and it refers to: number of complaints, volume of 
repeated reservations, volume of timely deliveries, customer waiting time, etc. But, we should not neglect the fact that financial performance views the interests of shareholders as a priority as they are the legal owners of companies.

In contrast, indicators assessing financial performance study and interpret the company accounts presenting its financial standing compared to competitors. Based on medium and longterm performance appraisal, the degree of incompetence in the process of governance is assessed and the long-term value of shares is calculated using updated values of future cash flows. Shortterm value of shares focuses around profit. In general, shareholders are concerned about: current and future income, dividend policy and investment risks.

Due to a study of E. Hansen and S. Schaltegger [7], the typology of performance is very diversified and different from one company to another. Epstein and Wisner (2001), representatives of academia, on the one hand, and Rohm and Montgomery (2011), representatives of business, on the other hand, view a company as a node where a set of social, environmental and non-financial problems meet on long-term. In this context, Figge (2002) discusses about the sustainability balanced scorecard seen as a proper instrument for solving such problems. In searching solutions for social and environmental problems, they conventionally integrated strategic management with sustainable development. So, there appeared a system developed by unifying the environmental, social and financial management, and they also suggested an efficient means for managing financial and non-financial performance [7].

Initially, the balanced scorecard was named prospectively and studied in detail by Kaplan and Norton. In 1992, they suggested an instrument turning perspectives and strategies into objectives and measures. P. Boisselier brings additional explanations stating that it transforms the business missions and strategies into a set of performance indicators (scorecard). The system focuses especially on financial objectives correlated with the means needed for reaching them. Performances are appraised depending on the four balanced axes (balanced): financial perspective, customer perspective, internal business process perspective and learning and grawth perspective. The financial axis is best known through financial indicators that a company may calculate. In case of sustainable scorecard, Figge and other researchers [7] identified the return on capital employed (ROCE) as the main indicator. It should reach a value between $6-8 \%$, turnover should grow by $20 \%$, and the return on sales should reach $4-4,5 \%$.

The customer axis is the second element and refers to the market segment targeted by the company. P. Boisselier states that the indicators used to evaluate the customer axis are very diversified. The first indicator refers to the market share that may be replaced with turnover and or relative market share. Attraction of new clients, customer return or company segment are very important for growing managerial performance. In another case, for the company Matra Marconi Space [8], the bankruptcy of a client created a decrease in sales, and implicitly, in profit. In terms of sustainable development, the customer axis is divided into two parts: strategic approach and the indicative performance indicators. Inadequate deliveries and compliance with the delivery deadlines are the main indicators. The strategic approach aims to grow the market share by 15 $20 \%$ as a result of customer satisfaction that may be assessed by following indicators: product 
features (real content of nutrients and toxins, expiry dates), relation with customers, company reputation and image.

The internal business axis refers to the processes that have a significant influence on customer satisfaction and financial objectives. Kaplan and Norton [8] identified three fundamental processes: innovation, production process and post-sale services. Strategic approach to internal processes according to Figge [7] does not differ much from Kaplan and Norton. Strategic directions of internal processes axis in the sustainable scoreboard refer to innovation, production processes and services. The second element of the internal processes axis refers to performance indicators, namely: quality control with the department of purchasing, use of substances contraindicated in manufacturing, energetic efficiency, quality of materials and water. Efficiency of energy consumption, materials and water result in the reduction of production cost. Quality control performed by the purchasing department aims to prohibit child labour, toxicity and expiry period for raw material.

The learning and growth axis identifies and monitors company development factors. Kaplan and Norton [8] identified the following factors: potential and responsibility of employees, potential of computer system, motivation and convergence of the aim and objectives. While Figge [7], as well as in the customer and internal processes axes, divides it into two parts: strategic approach and indicative performance indicators. Customer satisfaction is the only strategic direction assessed using performance indicators: potential of employees, technical infrastructure, health and security at the workplace.

Consequently, sustainable balanced scorecard aims to make operations more efficient by combining financial and non-financial performance appraisal indicators as an element of sustainable management control. Literature review was based on international bibliographical resources and their use was verified in different practical ways. Initially, we verified the degree of applicability of the scoreboard in the reports of administrators from the main segment of the Bucharest Stock Exchange (BSE). As a result, we discovered that only one company out of 39 reporting companies included information on the balanced scorecard. Later, the study was diversified, and the researched population extended.

\section{Materials and Methods}

In the theoretical section above on the relations between management control and company performance, we underlined both the financial and non-financial aspects of the sustainable scorecard. So, the study evaluates empirically the results presented above using data and information collected from companies in Romania based on the Annual Reports and by applying a statistical questionnaire.

The methodological elements needed for this stage are presented in relation with the research hypotheses that are checked by this paper. So, the following three hypotheses will be verified:

- $\quad \mathbf{H}_{1}$ : performance appraisal system of a company has a significant impact on sustainable management control; 
- H2: in sustainable management control, the return on capital employed is mostly used in the appraisal of financial performance;

- $\quad$ H3$_{3}$ : from the perspective of management control, financial responsibility is the most important element of stewardship.

To verify the first research hypothesis, we will use data collected from a questionnaire and econometric modelling as a method of statistical analysis. The sample of respondents includes top managers of companies listed on the regulated market and AeRO of the Bucharest Stock Exchange. Statistical data were collected in a larger survey research conducted in 2017.

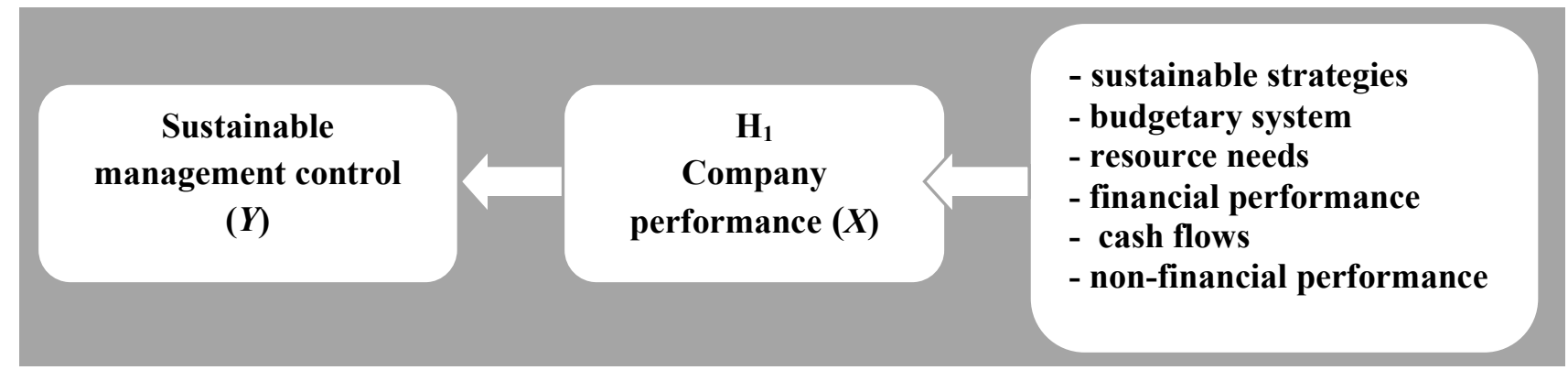

Figure 1. Scheme presenting the methodology used to verify the first research hypothesis

Scheme in Figure 1 explains the testing algorithm for the relations between management control, as dependent variable (Y), and company performance, through its elements, as independent variable (X). Questions in the statistical questionnaire enabled the collection of data using five-point Likert scale: total disagreement, disagreement, no agreement or disagreement, agreement, total agreement. This instrument was applied both to dependent and independent variable.

Dependent variable was represented by the following question: In your opinion, management control is an instrument of executive management used to optimise company performance?

The following questions provide data for independent variables:

- Q1. Does the level of development of sustainable strategies match the level of performance evolution of the company?

- Q2. Does your company examine entreprise resource planning to identify new problems, and to solve them?

- Q3. The budget is an important instrument for performance control?

- Q4. Financial performance directly influences company performance?

- Q5. How often the company uses cash flow to assess performance?

- Q6. The prospective scoreboard is the most efficient performance management method?

- Q7. To which extent your company uses product quality, market share, customer satisfaction in assessing performance?

The consistency of responses was checked using Cronbach's Alpha indicator. The consistency of the measurement scale is good due to coefficient 0.855 , higher than 0,7 . 
Measurement of effects of explicative variables (independent) on management control is made using multiple linear regression analysis:

$$
Y=\beta_{0}+\beta_{1} X_{1}+\beta_{2} X_{2}+\ldots+\beta_{7} X_{7}+\varepsilon
$$

To identify significant variables and to eliminate the insignificant ones, we used Stepwise procedure from SPSS 20.0 software. By estimating the regression model, we obtain regression coefficients showing partial contribution of independent variables to management control.

The second and third hypotheses were tested by analysing the reports of administrators for the year 2015. Data were collected from the web page of the Bucharest Stock Exchange (BVB) within the regulated market. Out of 50 companies with available data, companies from the financial sector were excluded, so that only 39 companies were left. The content analysis was used as a method for collecting information on management control, performance and company responsibility.

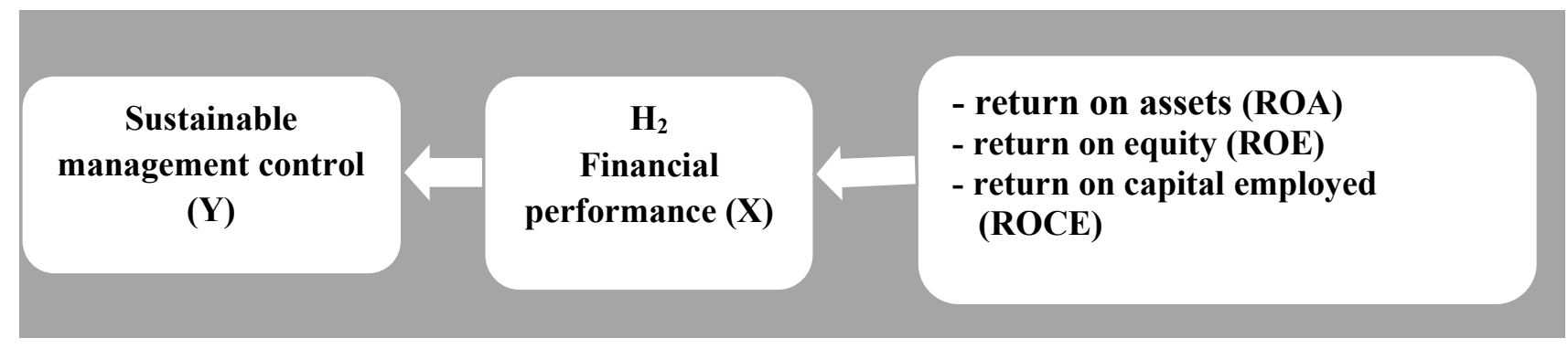

\section{Figure 2. Scheme presenting the methodology for assessing the second research hypothesis}

Scheme in Figure 2 presents the appraisal process of relations between sustainable management control, as dependent variable (Y), and financial performance, as independent variable (X). Financial performance is represented by return on capital employed. Out of 39 reports analysed in the study, we collected data related to: operating profit, net profit, total assets, current liabilities and equity. Based on these data, we calculated ROA, ROE and ROCE indicators. The reason for choosing these three indicators is based on the results obtained from the analysis of data from the statistical questionnaire. The questionnaire included also a set of questions linked to the importance of financial indicators in measuring company performance. We may note that seven indicators were included: ROCE, ROA, ROE, EVA (Economic Added Value), EBITDA (Earnings before interest, tax, depreciation and amortization), EPS (Earnings per share) and ROI (Return on investment). The results showed that respondents preferred the first three indicators included in this study, according to Figure 2.

To test the hypothesis $\mathrm{H}_{2}$, we used the binary logistic regression analysis. The dependent variable is binary as it differentiates the two categories of companies; companies presenting in the Annual Reports information on how management control is organised and companies which lack such information. Therefore, the dependent variable is given the values: 1 - Yes, 0 - No.

Binary logistic regression model has the following equation: 


$$
\begin{aligned}
& \ln \left(\frac{p}{1-p}\right)=\beta_{0}+\beta_{1} X_{1}+\beta_{2} X_{2}+\beta_{3} X_{3}+\varepsilon \text { or } \\
& \left(\frac{p}{1-p}\right)=e^{\beta_{0}+\beta_{1} X_{1}+\beta_{2} X_{2}+\beta_{3} X_{3}+\varepsilon}, \text { where }
\end{aligned}
$$

- $p$ presents the probability that dependent variable be 1 (success);

- 1- $p$ is the complementary probability (when the dependent variable is zero);

- $X_{1}, X_{2}, X_{3}$ represents the independent variables;

$-\frac{p}{1-p}$ represents the odds (odds).

The independent variables are the financial return indicators ROA, ROE and ROCE calculated based on the information from 39 Annual Reports. The three variables included in the model in the logarithm form.

The third hypothesis plays the role of verifying how companies from the main segment of the regulated market of BSE in the presentation of information in the Annual Reports take into account the provisions of Directive 2014/95/EU on the publication of non-financial information as to generate" responsible" growth. The relation with performance was inspired by the statement: that ,disclosure of non-financial information helps in the appraisal, monitoring and managing company performances and their impact on society" [9]. Additionally, according to institutional theory, the appraisal of company behaviour should be based on three aspects: legal, normative and cultural-cognitive [10].

In this sense, we studied the provisions of the quide Global Management Accounting Principles (2015) on sustainable approach to management control. Therefore, one of the features of management control is stewardship playing the role of building trust towards financial and accounting information provided by a company. The $\mathrm{H}_{3}$ research hypothesis was based on this approach.

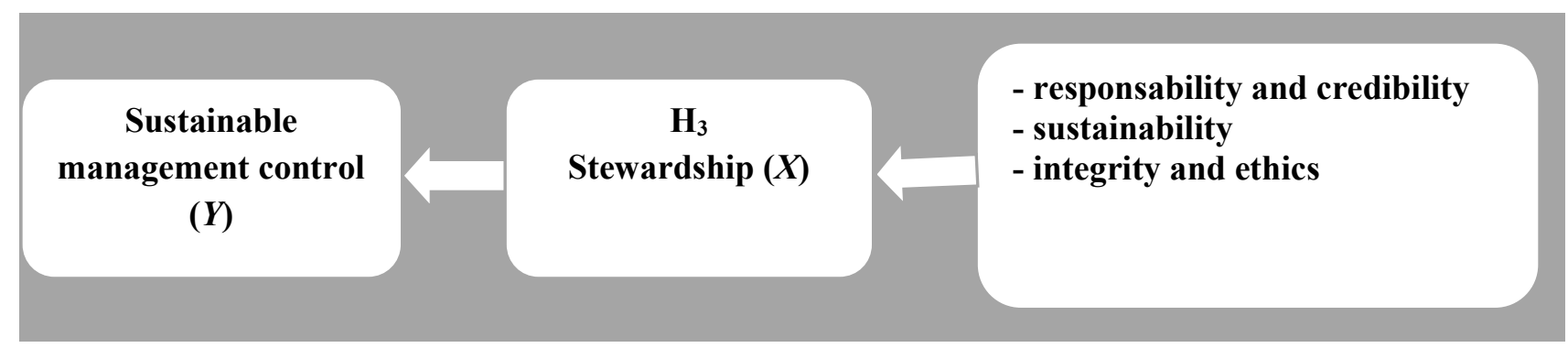

Figure 3. Scheme presenting the methodology verifying the third research

Scheme in Figure 3 the algorithm of the process of assessment of the relation between sustainable management control, as dependent variable (Y) and stewardship, as independent variable $(\mathrm{X})$, reflected by financial responsibility.

\section{Results and Discussion}


The analysis of the degree of association between management control and company performance was made using the Pearson correlation coefficient. To validate the hypothesis H1, we tested the significance of correlation intensity between dependent variable and the seven questions as independent variables.

Table 1. Correlation coefficient between management control and the elements defining company performance

\begin{tabular}{|l|c|c|c|c|c|c|c|c|}
\hline & $\begin{array}{c}\text { Management } \\
\text { control }\end{array}$ & Q 1 & Q 2 & Q 3 & Q 4 & Q 5 & Q 6 & Q 7 \\
\hline $\begin{array}{l}\text { Managemen } \\
\text { t control }\end{array}$ & 1 &, 019 &,- 074 &, 247 &, $400^{* *}$ &, 215 &, 022 &, 141 \\
\hline Q 1 &, 019 & 1 &, $306^{* *}$ &, $240^{* *}$ &, $272^{* *}$ &, $163^{*}$ &, 148 &, 125 \\
\hline Q 2 &,- 074 &, $306^{* *}$ & 1 &, $293^{* *}$ &, 146 &, $316^{* * *}$ &, $208^{*}$ &, $338^{* * *}$ \\
\hline Q 3 &, 247 &, $240^{* *}$ &, $293^{* *}$ & 1 &, $455^{* *}$ &, $252^{* * *}$ &, $217^{* *}$ &, $364^{* * *}$ \\
\hline Q 4 &, 400 &, $272^{* *}$ &, 146 &, $455^{* * *}$ & 1 &, 139 &, $177^{* *}$ &, $233^{* * *}$ \\
\hline Q 5 &, 215 &, $163^{*}$ &, $316^{* *}$ &, $252^{* *}$ &, 139 & 1 &, $474^{* *}$ &, $358^{* * *}$ \\
\hline Q 6 &, 022 &, 148 &, $208^{*}$ &, $217^{* *}$ &, $177^{*}$ &, $474^{* * *}$ & 1 &, $261^{* * *}$ \\
\hline Q 7 &, 141 &, 125 &, $338^{* *}$ &, $364^{* *}$ &, $233^{* *}$ &, $358^{* * *}$ &, $261^{* * *}$ & 1 \\
\hline
\end{tabular}

Correlation is significant starting with $0.01 / *$ Correlation is significant starting with 0.05

Source: own processing based on a questionnaire and SPSS 20.0.

The elements from Table 1 show positive correlations between management control variable and a set of independent variables describing main features of company performance. The values of correlation coefficients make us observe an association with the items Q3, Q4, Q5, Q7 from the questionnaire, reject the hypothesis $\mathrm{H}_{0}: \rho=0$, and accept the hypothesis $\mathrm{H}_{1}: \rho \neq 0$. The aim of this hypothesis was to show the general aspects of the relation between sustainable management control and company performance. Therefore, this link was verified by the budgetary system $(0,247)$, cash flow $(0,215)$, and non-financial performance $(0,141)$. But the most important link could be observed in financial performance $(0,400)$, the fact that was used to formulate the research hypothesis $\mathrm{H}_{2}$.

The estimation of regression model coefficients by calculating the determination ratio plays the role of maintaining in the model only the variables with statistically significant influence. This model has retained only financial performance Q4 that directly influences the coefficients: $\mathrm{b}=$ $0,578, t_{\text {calculated }}=3,772, \mathrm{sig}=0,001$. Also, we ran test $t$ to discover what is the probability for each parameter to be null.

Table 2. Regression coefficients of the model between management control and elements defining company performance

\begin{tabular}{|c|c|c|c|}
\hline \multicolumn{3}{|c|}{ Coefficients $^{\text {a }}$} & \\
\hline Model & Unstandardived & Standardi \\
Coefficients & $\begin{array}{c}\text { Zed } \\
\text { Coefficien } \\
\text { ts }\end{array}$ \\
\end{tabular}




\begin{tabular}{|c|c|c|c|c|c|}
\hline & $\mathbf{B}$ & $\begin{array}{l}\text { Std. } \\
\text { Error }\end{array}$ & Beta & & \\
\hline (Constant) & 1,685 &, 685 & & 2,459 &, 019 \\
\hline $\begin{array}{l}\text { Q4. Financial } \\
\text { performance }\end{array}$ &, 578 & ,155 &, 517 & 3,722 & ,001 \\
\hline $\mathbf{R}$ &, $517^{\mathrm{a}}$ & & & & \\
\hline R Square & ,267 & & & & \\
\hline Adjusted R Square &, 248 & & & & \\
\hline $\begin{array}{l}\text { Std. Error of the } \\
\text { Estimate }\end{array}$ &, 714 & & & & \\
\hline $\mathbf{F}$ & $\begin{array}{r}13,85 \\
6\end{array}$ & $\begin{array}{l}\text { Sig. }= \\
0,001^{\text {b }}\end{array}$ & & & \\
\hline
\end{tabular}

Source: own processing based on a questionnaire and SPSS 20.0.

The verification of working hypotheses $\mathrm{H}_{0}: \beta=0$ and $\mathrm{H}_{1}: \beta \neq 0$ was made on data from Table 2. In this sense, the Sig value should be less than 0.05 and shows that the slope of the regression line $(\beta)$ presents a significant link between the variables and was verified for each question:

- Q4: $\mathrm{H}_{0}: \beta 1=0, \mathrm{H}_{1}: \beta 1 \neq 0$; $t=\frac{b_{1}}{s_{\hat{\beta}_{1}}}=\frac{0,578}{0,155}=3,722, \operatorname{Sig}(\mathrm{t})=0,001<0,05$

- Q3: $\mathrm{H}_{0}: \beta 1 \neq 0, \mathrm{H}_{1}: \beta 1=0, \operatorname{Sig}(\mathrm{t})=0,758>0,05$;

- Q5: $\mathrm{H}_{0}: \beta 1 \neq 0, \mathrm{H}_{1}: \beta 1=0, \operatorname{Sig}(\mathrm{t})=0,952>0,05$;

- Q7: $\mathrm{H}_{0}: \beta 1 \neq 0, \mathrm{H}_{1}: \beta 1=0$, $\operatorname{Sig}(\mathrm{t})=0,630>0,05$.

Based on testing statistical hypothesis, the independent variable represented by question Q4 was retained in the model, and the other variable was excluded. Even though the correlation results in Table 1 present the associations between sustainable management control and performance by means of budgetary system, cash flow, financial and non-financial performance, the regression model using Stepwise showed that only financial performance has a significant influence on the sustainable success of a company.

The determination coefficient $\mathrm{R}$ Square $\left(\mathrm{R}^{2}\right)$ may be between $[0 ; 1]$ : if $\mathrm{R}^{2}=0$ or has a very small value, then the chosen regression model does not explain the link between the variables, and if $\mathrm{R}^{2}=1$, then all observations fall on the regression line and the model explains perfectly the link between the variables. The coefficient 0,267 from Table 2 shows that approximately $27 \%$ of management control variation is explained by company performance.

From this perspective, test $\mathrm{F}$ statistic with a reasonably high coefficient 13,856 calculated based on ANOVA regression analysis with a Sig. $=0,001^{\mathrm{b}}$ lower than 0.05 , showing that the independent variable (company performance) explains the variation of the dependent variable (sustainable management control) and vice versa.

While hypothesis $\mathrm{H}_{1}$ has a more general nature, then hypothesis $\mathrm{H}_{2}$ aims to test and validate the relations between management control and company financial performance. The 
coefficients of logistic regression model, its significance and model's significance are presented in Table 3.

Table 3. Coefficients of logistic regression model testing the relation between financial performance and management control

\begin{tabular}{|c|c|c|c|c|c|c|c|}
\hline \multicolumn{8}{|c|}{ Variables in the Equation } \\
\hline & & B & S.E. & Wald & $\begin{array}{l}d \\
f\end{array}$ & Sig. & $\begin{array}{c}\operatorname{Exp}( \\
\text { B) }\end{array}$ \\
\hline \multirow{4}{*}{$\begin{array}{l}\mathrm{St} \\
\text { ep } \\
\mathbf{1}^{\mathbf{a}}\end{array}$} & $\ln R O A$ & 1,213 & 1,366 &, 789 & 1 &, 374 & $\begin{array}{r}3,36 \\
4 \\
\end{array}$ \\
\hline & $\ln \mathrm{ROE}$ & 1,388 & 1,849 &, 563 & 1 & ,453 & $\begin{array}{r}4,00 \\
6\end{array}$ \\
\hline & $\operatorname{lnROCE}$ & $-3,045$ & 1,657 & 3,376 & 1 &, 066 & ,048 \\
\hline & Constant &,- 702 & 1,463 & ,230 & 1 &, 632 &, 496 \\
\hline \multicolumn{8}{|c|}{ Omnibus Tests of Model Coefficients } \\
\hline \multicolumn{2}{|c|}{ Chi-square } & \multicolumn{6}{|c|}{8,486} \\
\hline \multicolumn{2}{|c|}{ df } & \multicolumn{6}{|l|}{3} \\
\hline \multicolumn{2}{|c|}{ Sig. } & \multicolumn{6}{|l|}{0,037} \\
\hline
\end{tabular}

Source: own processing based on a questionnaire and SPSS 20.0.

Table 3 shows that only ROCE indicator has a significant effect on companies disclosing information on management control, the Sig value of Wald test is less than the undertaken risk of $10 \%$. In this sense, we observe that financial indicators are commonly used in performance evaluation, and ROCE is preferred especially by companies disclosing information on sustainable management control in the Annual Reports.

The second hypothesis was tested by both econometric models, as well as conceptual content analysis viewed as a qualitative analysis method. To verify the authenticity of ideas presented in the theoretical part of this study, data were collected from the Annual Reports within the regulated market of BSE and presented in figures $4,5,6,7,8$.

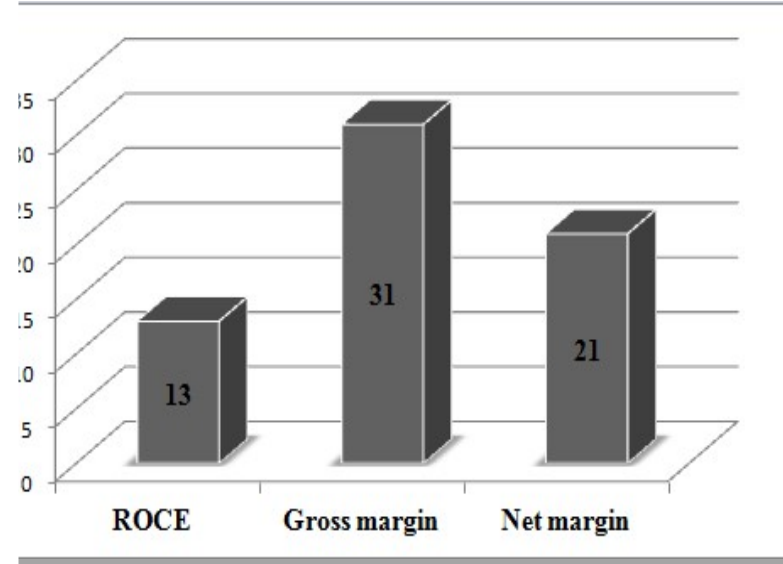

Figure 4. Profitability indicators (\%)

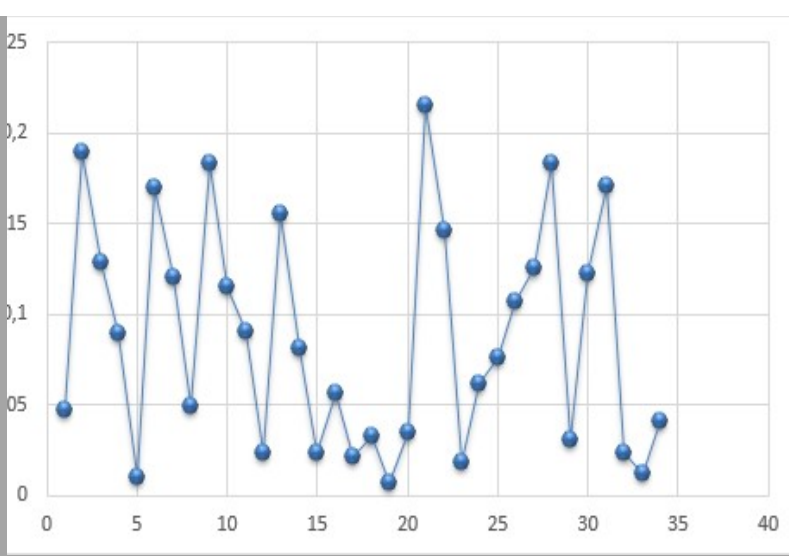

Figure 5. ROCE presentation

Source: own processing based on the reports of administrators, BSE. 
Figure 4 shows the degree of use of profitability indicators. The highest share of $31 \%$ is found in gross profit margin, namely, 12 out of 39 companies calculate this indicator. $13 \%$ of companies use ROCE, while 21\% use gross profit margin. Even though ROCE has the lowest frequency use, still recent studies in the field report that it is the most representative indicator in sustainable performance evaluation. So, based on available data, it was calculated for 34 out of 39 companies (4 reported losses in the studied period). Figure 5 shows ROCE variation from one company to another, the lowest coefficient is 0,07 , and the highest is 0,215 .

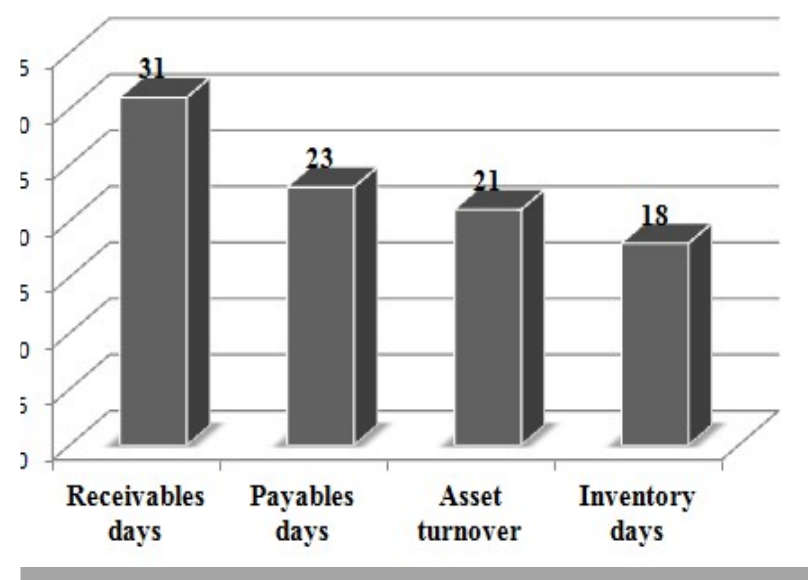

Figure 6. Indicators of economic and financial efficiency $(\%)$

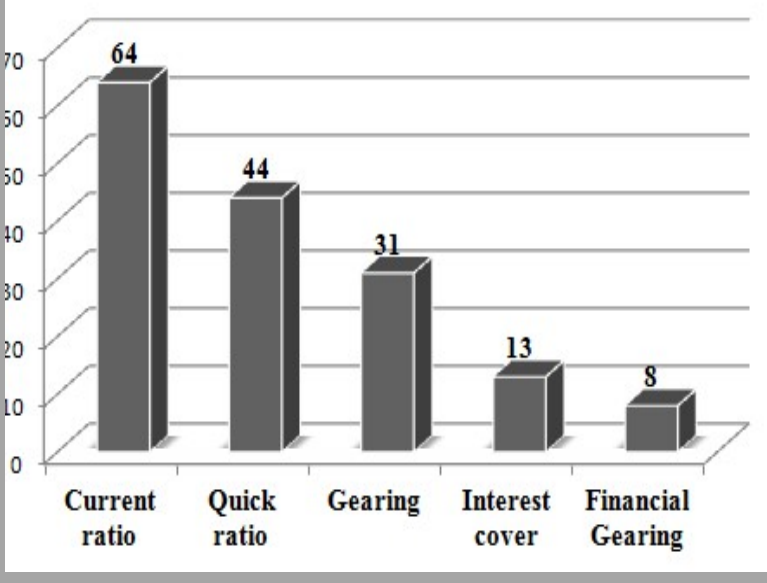

Figure 7. Liquidity and degree of indebtedness indicators (\%)

Source: own processing based on the reports of administrators, BSE.

The analysis of pragmatic situation of financial and economic efficiency appraisal indicators shows their common use by local companies. Receivables turnover ratio from Figure 6 has the highest amount of $31 \%$. The share of other ratios enables us to state that the indicators measuring financial and economic efficiency should be used in performance evaluation even if these are less known. Current liquidity ratio in Figure 7 had the highest share of $64 \%$ also showing the importance of liquidity ratios in appraising performance.

Johan Wolfgang Goethe was perfectly right when he said that ,figures do not rule the world, but show the way it is ruled" [11]. Profit has been until recently the main element in appraising the financial health of a company. Now, it has been replaced by a multitude of instruments. The sustainable scorecard is one of these instruments, but the results of the analysis of Annual Reports showed that only one company out of 39 included in the study used the prospective scorecard. This is the reason why we continued the study based on stewardship that, according to the Guide Global Management Accounting Principles (2015) plays the role of building trust by means of the following elements: responsibility and credibility, sustainability, integrity and ethics. This approach was used in the formulation of research hypothesis $\mathrm{H}_{3}$. So, based on conceptual content analysis, we extracted information on features of stewardship. 


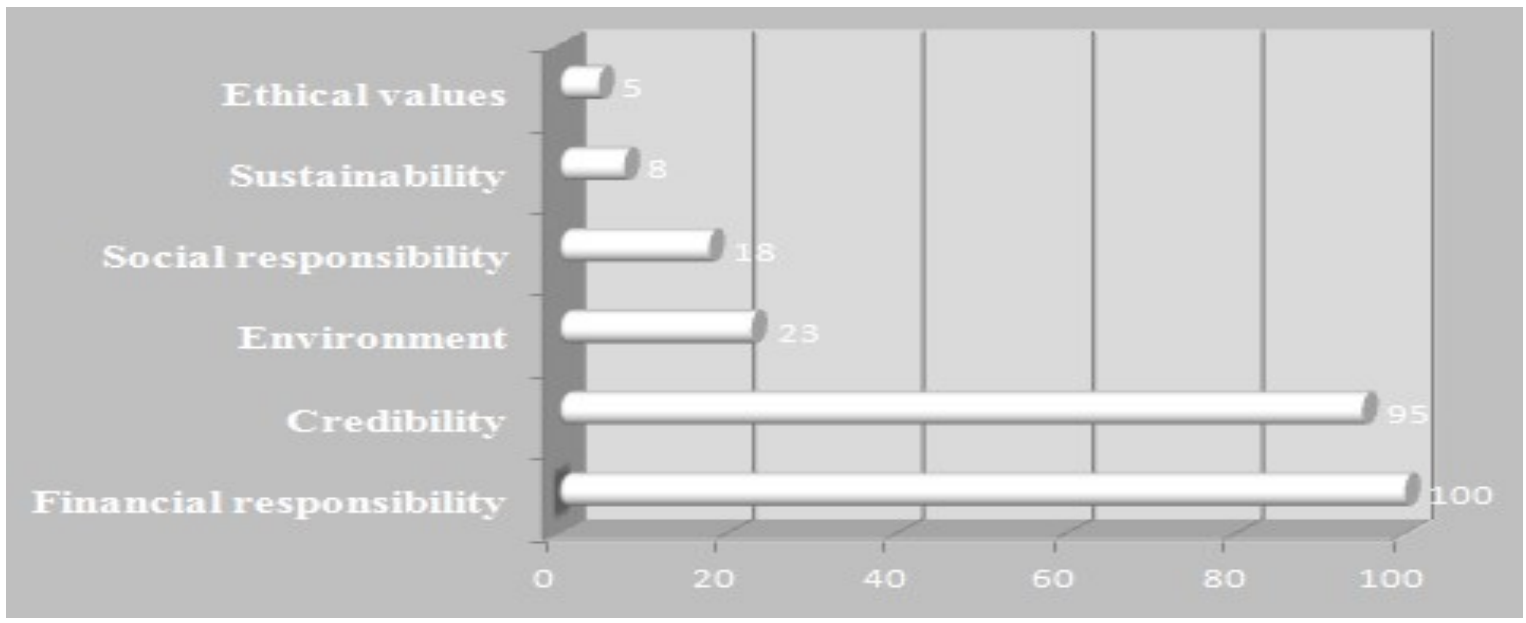

Source: own processing based on the reports of administrators, BSE

Figure 8. Elements of Stewardship (\%)

The share of $100 \%$ in Figure 8 shows that 39 companies included in their Annual Reports information on financial responsibility. So, all companies at the moment of submitting the financial report of the company enclosed also the statement on financial responsibility or a financial audit report. Credibility is the category justified by the accounting policies presented in the report annexes. The share of $95 \%$ proves that most companies implement adequate accounting policies. Even if other categories have a lower share, still the fact that some companies are not indifferent towards ethical values (5\%), sustainability (8\%), social responsibility (18\%), and environment (23\%) make us state that Romanian companies have doubts about a prosperous future.

The third hypothesis has been tested using qualitative methods as the independent variable amounted to $100 \%$ and could be included in testing an econometric model.

\section{Conclusions}

Economic development of a company is a symbol of success due to inherent conditions requiring that economic operations be profitable and contribute to performance. Generally, this notion is linked to extraordinary results a company achieves in its field of activity. But, if we talk about performance in terms of professional terminology, then we should focus our research on financial and non-financial elements.

Performance reflects a success or all well-thought actions that a company can measure. The elements of performance differ from one author to another but all companies should on competencies of employees and their attitude towards achieving targets. Resource-based theory is the theoretical and conceptual background that supports the relations between management control and performance.

Sustainable balanced scorecard contributes to improving the efficiency of economic operations viewed as an element of control in managing performance. Its four parts include both financial and non-financial performance indicators. Besides guiding the executive management in its daily operations, the prospective scorecard takes into account new approaches in the field 
related to the notion of sustainable development of a company. It provides a set of solutions to problems that appear in the process of turning the vision of the board of directors into strategic objectives, budgets and performance-led actions.

Also, the company size, its organizational structure and type of activity require different methods for performance evaluation. The research in the field showed that complex businesses require sophisticated systems, and their design, implementation and operation impose high costs that are not affordable by small companies. In companies with a high need for interaction among their units, the performance appraisal system provides a general communication terminology for managers at different levels.

The study has following limitations:

- it did not study also the relations of corporate governance;

- the study focused more on financial performance to the detriment of non-financial ones;

- it did not analyse in detail each category of financial indicators.

Future research should focus on the following issues:

- correlation of performance evaluation system with sustainable development using societal performance;

- study in detail of each element of prospective scoreboard in relation with sustainable development;

- influence of management control on the economy of a country using macroeconomic performance.

\section{Bibliografie}

1. Sonnentag, S., Frese, M., 2002, Performance Concepts and Performance Theory, Psychological Management of Individual Performance. Sabine Sonnentag: John Wiley \& Sons, Ltd., pp. 3-25.

2. Cappelletti, L., 2008, Vers un contrôle de gestion intégré à la fonction commerciale : cas d'expérimentation, Management \& Avenir, 2 ( $\left.{ }^{\circ} 16\right)$, pp. 156-173.

3. Gervais, M.(coord.), 1996, Recherches en Contrôle de gestion. Paris: Editura Economica.

4. Braganza, A., Stebbings, H., Ngosi, Th., 2013, The case of customer recruitment processes: Dynamic evolution of customer relationship management resource networks, Journal of Marketing Management, Vol. 29, Nr. 3-4, pp.439-466.

5. Liu, Y., 2011, Performance-based funding and budgeting in higher education Jackson State University, Copyright: NAAAS \& Affiliates Conference Monographs, pp.1516-1539.

6. Association of Chartered Certified Accountants and the Chartered Institute of Management Accountants, 2008, P5 Advanced performance management, Published by: Kaplan Publishing UK Unit 2 The Business Centre Molly Millars Lane Wokingham Berkshire RG41 2QZ.

7. Hansen, E., Schaltegger, S., 2014, The Sustainability Balanced Scorecard: A Systematic Review of Architectures, Joumal of Business Ethics, Springer, pp. 1-29.

8. Boisselier, P., Chalençon, L., Doriol, D., Jardin, P., Mard, Y., Mayrhomer, U., 2013, Contrôle de gestion, Magnard-Vuibert-Août. 
9. Burlaud, A., Niculescu, M., 2015, Informaţia nonfinanciară: o perspectivă europeană, Audit financiar, XIII, Nr. 6(126), pp. 43-53.

10. Herremans, I. M., Nazari, J., A., 2016, Sustainability Reporting Driving Forces and Management Control Systems, Journal of management accounting research American Accounting Association, vol. 28, No. 2, pp. 103-124.

11. Colasse, B. Les fondements de la comptabilité. Traducere de N. Tabără. Éditions La Découverte, Paris, 2007, 128 p.

12. Bîrcă, A., 2017, Controlul de gestiune în optimizarea performanței entității, Editura Tipo Moldova, Iași.

13. Biazzo, S., Garengo, P., 2012, Performance Measurement with the Balanced Scorecard. A Practical Approach to Implementation within SMEs, Springer-Verlag Berlin Heidelberg.

14. Chai, Nan, 2009, Sustainability Performance Evaluation System in Government. A Balanced Scorecard Approach Towards Sustainable Development, Springer Science, Business Media B.V.

15. Charlo, M., Moya, I., Muñoz, A., 2015, Sustainable Development and Corporate Financial Performance: A Study Based on the FTSE4Good IBEX Index, Business Strategy and the Environment, volume 24, issue 4, May, pp. 277-288.

16. Demartini, C., 2014, Performance Management Systems, Contributions to Management Science, C Springer-Verlag Berlin Heidelberg.

17. Essoua, B., 2006, Cohérence logique entre le modèle stratégico-opérationnel en contrôle de gestion et la théorie de la firme-compétence foncière des économistes évolutionnistes : une lecture historique, Comptabilité - Contrôle-Audit, nr. 3, Tome 12, pp. 139-161.

18. Fornerino, M., Godener, A., Ray, D., 2010, La satisfaction des managers vis-à-vis du contrôle de gestion et leur performance managériale, Comptabilité - Contrôle - Audit, Association francophone de comptabilité, nr. 3, pp. 101-126.

19. Gani, L., Jermias, J., 2012, The Effects of Strategy-Management Control System Misfits on Firm Performance, Accounting Perspectives, Canadian Academic Accounting Association, No. 3/ 11, pp. 165-196.

20. Gray, J., Handley, S., 2015, Managing contract manufacturer quality in the presence of performance ambiguity, Journal of Operations Management, volume 38, September, pp. 41-55.

21. Guedj, N. (coord.), 2000, Le contrôle de gestion pour améliorer la performance de l'entreprise, Éditions d'Organisation, Paris.

22. Gumb, B., 2005, Des mythes fondateurs du contrôole de gestion et de ses prolongements : le cas de l'informatique decisionnelle, Business administration. Universite Robert Schuman Strasbourg III, L'archive ouverte pluridisciplinaire HAL.

23. Hales, J., Rees, L., Wilks, J., 2016, A Synthesis of Three Commentaries on Measurement and Performance Reporting, Accounting horizons, American Accounting Association, no. 4/30, pp. $473-483$.

24. Kaplan R., Norton D., 1996, 1998 (édition française), The Balanced Scorecard: Translating Strategy Into Action, Harvard Business School Press Boston, Massachusetts.

25. Larmou, S., Vafeas, N., 2010, The relation between board size and firm performance in firms with a history of poor operating performance, Journal of Management Governance, nr.14, pp. 61-85.

26. Manzoni, A., Islam, S., 2009, Performance Measurement in Corporate Governance, DEA Modelling and Implications for Organisational Behaviour and Supply Chain Management, Springer Dordrecht Heidelberg London New York, (c) Physica-Verlag Heidelberg. 
27. Sen, P., Roy, M., Pal, P., 2015, Exploring role of environmental proactivity in financial performance of manufacturing enterprises: a structural modelling approach, Journal of Cleaner Production, nr.108, pp. 583-594.

28. Trafimow, D., Hunt, G., Rice, S., Geels, K., 2011, Using Potential Performance Theory to Test Five Hypotheses About Meta-Attribution, The Journal of General Psychology, Copyright: Taylor \& Francis Group, 138 (2), pp. 81-93.

29. Trumpp, C., Endrikat, J., Zopf, C., Guenther, E., 2015, Definition, Conceptualization, and Measurement of Corporate Environmental Performance: A Critical Examination of a Multidimensional Construc, Journal of Business Ethics, Springer Science+Business Media Dordrecht, pp. 185-204.

30. Zenita, R. , Sari, R., Anugerah R., Said, J., 2015, The Effect of Information Literacy on Managerial Performance: The Mediating Role of Strategic Management Accounting and the Moderating Role of Self Efficacy, International accounting and business conference, IABC, Procedia Economics and Finance nr. 31, pp. 199 - 205.

31. Bucharest Stock Exchage. Available online: http://www.bvb.ro (accessed on 20 March 2018).

32. Global Management Accounting Principles, Chartered Global Management Accountant. Available online:

http://www.cgma.org/content/dam/cgma/resources/reports/downloadabledocuments/globalmanagement-accounting-principles-9.pdf (accessed on 3 March 2018). 